\title{
Molecular Surveillance of the Newcastle Disease Virus in Domestic and Wild Birds on the North Eastern Coast and Amazon Biome of Brazil
}

\section{-Author(s)}

Thomazelli LM*

Araujo J de

Ferreira $C$ de $S$

Hurtado R

Oliveira DB

Ometto T

Golono M

Sanfilippo L

Demetrio C

Figueiredo ML

Durigon EL

Instituto de Ciências Biomédicas - ICB

Universidade de São Paulo

\section{Mail Adress}

LM Thomazelli

Instituto de Ciências Biomédicas

Universidade de São Paulo

Av. Professor Lineu Prestes, 1374

São Paulo, SP, Brazil.

E-mail: lucmt@usp.br

\section{-Keywords}

Avian disease, avian paramyxovirus, Newcastle disease virus, South America, wild birds.

\begin{abstract}
Brazil is one of the world's largest countries with a rich diversity of wildlife, including resident and migratory wild birds, which may be natural reservoirs of the Newcastle disease virus (NDV). Because Brazil is a major global exporter of chicken meat, the emergence of such a disease may have a huge negative impact not only on the economy due to trade restrictions and embargoes, but also on the quality of life of the population. Samples were collected from 1,022 asymptomatic domestic and wild birds from the Brazilian coast and the Amazon region using tracheal/cloacal swabs and tested by RT-qPCR. The results showed $7(0.7 \%)$ birds were positive for NDV. The positive samples were then isolated in embryonated chicken eggs and their matrix protein genes were partially sequenced, revealing a low-pathogenicity NDV. This study confirms the maintenance of the velogenic-NDV free status of Brazil.
\end{abstract}

\section{INTRODUCTION}

Brazil participated with $43.4 \%$ share in the international chicken meat trade in 2010, maintaining its position as the world's largest exporter since 2004. Production reached 12.2 million tons, a result that kept the country as the third largest producer, only behind the USA and China. Chicken meat exports generated revenues of almost US\$ 6.8 billion in 2010 for Brazil (UBABEF, 2010/2011).

Chicken meat is important not only for Brazilian economy, but it is also a source of affordable, high-quality protein for the population. White meat essentially has the same nutrients as red meat, but it has the advantage of containing less saturated fat and cholesterol (Venturiniet al., 2007).

For many Brazilians, especially in the North and Northeast of the country, as well as in other developing countries, backyard layers and meat are extremely important protein sources of their diet.

The emergence of diseases such as Newcastle disease (ND), which is highly contagious with great lethal and epidemic potential and affects both domestic poultry and wild birds, may have a very negative impact not only on the economy of a country due to trade restrictions and embargoes, but also on the life quality of a large part of the population.

Although Brazil is considered free from Newcastle disease (ND) and the stringent prophylactic measures put in place by health authorities, according to OIE recommendations, its huge territory presents a wide diversity of wildlife, including resident and migratory wild birds, which may be natural reservoirs or carriers of the ND virus, since many migratory birds come from regions where NDV is endemic.

Therefore, we conducted a molecular epidemiological surveillance of NDV in different regions of Brazil presenting considerable bird 
migration, including the Amazon region, which is the entry portal of the major Brazilian avian migratory fly ways known, and the Northeastern coast, an area with many known wintering points.

\section{MATERIALS AND METHODS}

\section{Logistics}

The active surveillance of wild birds is challenging due to practical, logistic and financial obstacles. Considering the low prevalence of studied viruses and the limited resources available to finance surveillance effort, clear strategies needed be defined, both in the field and in the laboratory, in order to obtain samples that would indirectly provide us NDV monitoring data of migratory birds in Brazil. We mean indirectly because we collected few samples from wild birds, due to the difficulties described above. Therefore, we collected samples mainly from domestic birds that could potentially serve as "sentinels". We gave greater emphasis to study species that: were known to have been infected by NDV, were epidemiological reservoirs of NDV (for example, domestic ducks can carry the virus without showing symptoms), had greater contact with other wild species (migrating or not), and that shared the habitat with other animals, mainly birds rearedin backyards or lakes.

Two vehicles, purchased and equipped with the financial support of FAPESP with in the Viral Genetic Diversity Network project (VGDN - Process 00/115116) were used. The vehicles, a Land Rover Defender 110 and a Ford F-350, both had four-wheel traction and were equipped for off-road trails in order to enable sample collection in difficult access areas. One of the vehicles was adapted to contain a mobile lab, with all the necessary equipment to carry out the techniques for capturing, collecting, and processing material in situ. A boat, a generator, a centrifuge, tables, refrigerator, liquid-nitrogen cylinders, nets, cages, hand nets were some of the materials used.

With the permission of the Brazilian Institute of Environment and Renewable Natural Resources (IBAMA), we developed and followed protocols approved by the Ethics Committee on Animal Experimentation of the Institute of Biomedical Sciences, University of São Paulo, which tried to maximum reduce the potential for both human and animal exposure to the virus. were strategically placed between 30 and $250 \mathrm{~cm}$ high with in protected forest areas and/or open-field corridors in forest edges. Backyard poultry and those reared in small farms were captured using hand nets.

\section{Screening and identification}

Bird identification and biometric information were entered in spread sheets for further analysis, if necessary. The spreads heet included biological status: new bird, recaptured, recovered; age:adult, young, nestlings, undefined; identification, made by an ornithologist: species, order; sex:male, female, unspecified; and wing, tarsus, tail, nostril-tip and weight measurements. The studied birds were marked with a violet dye diluted in water at the time of release so that, if recaptured, they could be easily identified. Finally, the collected data were used to estimate the amount of blood to be collected and to define bird developmental stage.

\section{Collection of the specimens}

Between 2005 and 2007, the team collected 1,022 asymptomatic birds (848 specimens of domestic birds and 174 specimens of wild birds) that belonged to 40 different species. The samples were obtained from wild and domestic birds, with great potential for being "sentinels" (non-vaccinated birds reared in remote regions and in direct contact with other wild birds, including migratory birds) in several locations on the northeastern coast and in the Amazon biome, both in Brazil.

\section{Sample collection}

Samples were collected from individual birds by swabbing the cloacae and the orotrachea with two sterile cotton wool swabs each. One pair of swabs from the orotracheal and one from cloacal areas were then placed inside a micro tube containing 5\% glycerolMEM media $\mathrm{pH} 7.2$ with $100 \mathrm{U} / \mathrm{mL}$ of penicillin and $100 \mathrm{U} / \mathrm{mL}$ streptomycin. The other pair was placed in amicro tube containing Brazol reagent (LGCBio). The microtubes were immediately frozen in liquid nitrogen. Venipuncture of the brachial vein was performed in the mid-third of the humeral part of the flipper or in the jugular vein, depending on bird size. Blood was collected in syringes $(0.3-3 \mathrm{~mL})$ and transferred to microtubes, that were centrifuged $(3000 \mathrm{xg} / 10 \mathrm{~min})$ in the evening. The serum was then aspirated into individual sterile plastic vials and stored in liquid nitrogen.

RNA extraction, RT and Real-Time PCR (qPCR) RNA was extracted from the samples placed in Brazol

\footnotetext{
For the capture of wild passerine birds, mist nets
} 
Reagent (LGCBio), according to the manufacturers' instructions. The cDNA was generated using random primers and the assay was processed with the HighCapacity cDNA Archive kit (Applied Biosystems). Viral sequences were amplified byReal-Time PCR ( $P P C R$ ) using primers targeting the matrix gene segment previously described by Wise (2004). Cycling was performed using a Real Time 3300 PCR System (Applied Biosystems) with a program of 45 cycles of $15 \mathrm{~s}$ of denaturation at $94^{\circ} \mathrm{C}, 30 \mathrm{~s}$ of an nealing at 60 ${ }^{\circ} \mathrm{C}$, and $32 \mathrm{~s}$ of extension at $72{ }^{\circ} \mathrm{C}$.

The positive samples were submitted to a new qPCR reaction using the same conditions and reagents as described above, but with primers and a probe designed to complement the F-gene (fusion gene) of mesogenic and velogenic strains, in order to molecularly check their pathogenicity (Camenisch et al., 2008).

\section{Virus isolation}

The freezing media samples corresponding to the samples determined as positive by qPCR were inoculated in embryonated chicken eggs for viral replication. Samples were centrifuged at 3000xg for $30 \mathrm{~min}$ and the supernatant was collected and filtered in a filter membrane $(0.22 \mu \mathrm{m})$. The filtered liquid was used as inoculating material after aseptic examination, with $0.2 \mathrm{ml}$ inoculated in the allantoic cavity of 10-dayold specific pathogen-free (SPF) embryonated chicken eggs. Each sample was inoculated in three eggs. After $72 \sim 96 \mathrm{~h}$ of incubation at $37^{\circ} \mathrm{C}$, eggs were chilled and their allantoic fluids were harvested. The undiluted allantoic fluids were submitted to two continuous generation passages, then harvested for virus detection by $q P C R$.

\section{Mean death time (MDT) in eggs}

MDT was determined in embryonated chicken eggs to biologically check the pathogenicity of NDVs. Briefly, three 10-day-old embryonated chicken eggs were infected with serial 10-fold dilutions of viruses. The eggs were incubated at $37{ }^{\circ} \mathrm{C}$ and monitored twice daily for seven days. The time required to kill the embryos was recorded. The highest dilution that killed all embryos was considered as the minimum lethal dose. MDT was calculated as the mean time required for the minimum lethal dose to kill the embryos. NDV strains are classified as: velogenic (taking less than 60 hours to kill); mesogenic (taking between 60 and 90 hours to kill); and lentogenic (taking more than 90 hours to kill) (OIE, 2004).

\section{Nucleotide sequencing and phylogenetic analysis}

The recovered $P C R$ products were purified with the ExoSap-IT enzyme (GE) and were submitted to direct double-stranded nucleotide sequencing using BigDye Terminator Cycle Sequencing Ready Reaction Kit - AmpliTaq DNA Polymerase (Applied Biosystems) in the presence of the specific primers used for qPCR ( $\mathrm{M}$ gene) without the probe. The GenBank accession numbers of the sequences reported in this article and sequences representing different NDV genotypes used from public domain are listed in the legend of Figure 2 . The alignment of the nucleotide sequences and the deduced amino acid sequences of genes were conducted using the Bioedit Sequence Alignment Editor program, version 6.0.7, and the tree based on the nucleotide sequences from a portion of the $\mathrm{M}$ gene (121 bp) was constructed by the Distance method using the PAUP* program, version 4.0. The 100 replicas were boots trapped to construct a consensus phylogenetic tree.

\section{RESULTS}

\section{Sample collection}

Out of the 1022 samples, 743 were collected from wild or domestic water fowl, which accounted for $72.7 \%$ in total number. The detailed data of collection is shown in Table 1.

\section{NDV detection (qPCR)}

All cloacal/tracheal samples (1022) were tested by qPCR targeting the matrix gene segment of APMV-1, and $7(0.7 \%)$ were positive. The positive samples were also tested by qPCR targeting the fusion gene sequence of velogenic/mesogenic isolates (Wise, 2004), but none of these isolates were detected, indicating that they belonged to lentogenic strains.

Out of the five positive samples detected in birds from the Northern region (Amazon biome), one sample (sample 844BR) was obtained from a duck from small farm in the city of "Vigia de Nazaré" in 2005 and four other samples were collected in 2006: two samples (samples 2320BR and 2331BR) from backyard ducksin the city of "Breves" and two samples (samples 1773BR and 1777BR) from ducks from a small farm in the city "Terra Alta". The other two positive strains (2665BR and 2675BR) were isolated from shore birds, Calidrisalba and Calidrispusilla, in the Northeastern region in 2007. 
Table 1 - Complete data of the collected specimens.

\begin{tabular}{|c|c|c|c|}
\hline Location (region) & $\begin{array}{l}\text { GPAS } \\
\text { (date) }\end{array}$ & Collected species (no of entity) & Collected amount \\
\hline $\begin{array}{l}\text { Monte Negro - RO } \\
\text { (North) }\end{array}$ & $\begin{array}{c}10^{\circ} 15^{\prime} \mathrm{S} \\
63^{\circ} 17^{\prime} \mathrm{O} \\
\text { (Jul/2005) }\end{array}$ & $\begin{array}{l}\text { Myrmotherula hauxwelli (1) } \\
\text { Myrmotherula longipennis (1) } \\
\text { Myrmotherula nigrocinereus (2) } \\
\text { Mionectes macconneli (1) } \\
\text { Thamnophilus nigrocinereus (2) } \\
\text { Chiroxiphia pareola (1) } \\
\text { Momotus momota (1) } \\
\text { Chiroxiphia ocellatus (1) } \\
\text { Phaethornis hispidus (3) } \\
\text { Ramphocelus carbo (5) } \\
\text { Formicivora grisea (3) } \\
\text { Thaminophillus aethiops (1) } \\
\text { Thryothorus genibarbis (2) } \\
\text { Cnemotricus fuscatus (1) } \\
\text { Tolmomyas poliocefalus (1) } \\
\text { Nycotidromus albicolis (1) } \\
\text { Thaminophillus schistaceus (1) } \\
\text { Pipra fascicaudata (1) } \\
\text { Not identified (2) }\end{array}$ & 31 \\
\hline Vigia/Marabitanas - PA & $\begin{array}{c}0^{\circ} 53^{\prime} \mathrm{S} \\
47^{\circ} 59^{\prime} \mathrm{O} \\
(\mathrm{Jul} / 2005)\end{array}$ & $\begin{array}{l}\text { Domestic duck - Cairina moschata (235) } \\
\text { Turkey - Meliagres gallopavo (28) } \\
\text { Venilionis affinis (1) } \\
\text { Tyraneutes stolzmanni (2) } \\
\text { Thamnophilus aethiops (2) } \\
\text { Thamnophilus nigrocinereus (1) } \\
\text { Passerina cyanoides (1) }\end{array}$ & 270 \\
\hline $\begin{array}{l}\text { Vigia/Marabitanas/São } \\
\text { Caetano de Odivelas; } \\
\text { São Sebastião da Boa } \\
\text { Vista, Ilha do Marajó - } \\
\text { PA (North) }\end{array}$ & $\begin{array}{c}1^{\circ} 42^{\prime} \mathrm{S} \\
49^{\circ} 31^{\prime} \mathrm{O} \\
(\mathrm{Jul} / 2006)\end{array}$ & $\begin{array}{l}\text { Domestic duck - Cairina moschata (386) } \\
\text { Wild duck - Cairina moschata (8) } \\
\text { Chicken - Gallus gallus (7) } \\
\text { Turkey - Meliagres gallopavo (28) } \\
\text { Egretta thula (1) } \\
\text { Euxenura maguari (1) } \\
\text { Larus sp (1) }\end{array}$ & 502 \\
\hline $\begin{array}{l}\text { Breves, Ilha do Marajó - } \\
\text { PA (North) }\end{array}$ & $\begin{array}{c}1^{\circ} 40^{\prime} \mathrm{S} \\
50^{\circ} 28^{\prime} \mathrm{O} \\
(\mathrm{Oct} / 2006)\end{array}$ & $\begin{array}{l}\text { Domestic duck - Cairina moschata (79) } \\
\text { Chicken - Gallus gallus (6) }\end{array}$ & 85 \\
\hline Bragança - PA (North) & $\begin{array}{c}1^{\circ} 03^{\prime} \mathrm{S} \\
46^{\circ} 47^{\prime} \mathrm{O} \\
(\text { Nov/2006) }\end{array}$ & $\begin{array}{l}\text { Sterna hirundo (7) } \\
\text { Calidris canutus (3) } \\
\text { Calidris pusilla (3) } \\
\text { Actites macularia (15) } \\
\text { Domestic duck - Cairina moschata (8) }\end{array}$ & 36 \\
\hline $\begin{array}{l}\text { São Bento/Cajapió - } \\
\text { MA (Northeast) }\end{array}$ & $\begin{array}{c}2^{\circ} 41^{\prime} \mathrm{S} \\
44^{\circ} 49^{\prime} \mathrm{O} \\
(\mathrm{Apr} / 2007)\end{array}$ & $\begin{array}{l}\text { Turkey - Meliagres gallopavo (28) } \\
\text { Dendrocygna viduata (18) } \\
\text { Dendrocygna aytymnalis (44) } \\
\text { Netta Erythrophthalma (2) } \\
\text { Gallinula chloropus (2) } \\
\text { Amazonetta brasiliensis (4) } \\
\text { Anas sp (3) }\end{array}$ & 74 \\
\hline $\begin{array}{l}\text { Coroa do Avião, Itama- } \\
\text { racá - PE (Northeast) }\end{array}$ & $\begin{array}{c}7^{\circ} 48^{\prime} \mathrm{S} \\
34^{\circ} 50^{\prime} \mathrm{O} \\
(\mathrm{Apr} / 2007)\end{array}$ & $\begin{array}{l}\text { Arenaria interpres (6) } \\
\text { Calidris alba (10) } \\
\text { Calidris pusilla (5) } \\
\text { Charadrius semipalmatus (3) }\end{array}$ & 24 \\
\hline Total & & & 1022 \\
\hline
\end{tabular}

\section{NDV isolation}

Viral replication was performed by inoculating embryonated eggs with seven aliquots of the viral transport medium corresponding to the $\mathrm{QPCR}$ positive samples. The amplification of NDV matrix gene by qPCR was negative in the first and second passage for all samples. NDV was successfully isolated in the third passage, in which the virus was detected. The cycle threshold (ct) results were between 35 and 39 cycles with the threshold manually selected to a minimum above the noiseband (to increase sensitivity).

\section{Pathotype}

In addition to molecular pathotyping, each isolate sample was biologically evaluated as to the time it took to kill the embryo in the MDT test. All the $\mathrm{qPCR}$ positive samples (844BR, 1773BR, 1777BR，2320BR，2331BR， 2665BR and 2675BR) were characterized as lentogenic strains because MDT values were higher than 90, presenting average MDT values of 100, 156, 156, 156, 156, 148 and 156, respectively.

\section{Nucleotide and predicted amino acid sequences}

In order to assess the genetic relationship among Brazilian isolates and different NDV strains, the partial nucleotide sequences of the $M$ gene region covering nucleotide positions 4100-4220 were aligned and analyzed (Figure 1). The analysis included the corresponding sequences of reference strains and isolates previously reported in GenBank, representing the nine genotypes described to date (except for genotype eight).

The results of the phylogenetic analysis are shown in Figure 2. NDV isolates 1777BR, 2320BR, 2331BR, 2665BR, and 2675BR consisted of a separate cluster (95.9-100\% similarity), closely related to the Ulster strain of genotype I (95-98.3\% similarity). The 1773BR isolate (95.9-97.5\% similarity with Brazilian isolates) was more related with the $98 i 1252$ and 99 i0655 strains (99.2\% similarity) also belonging to genotype 1 . 


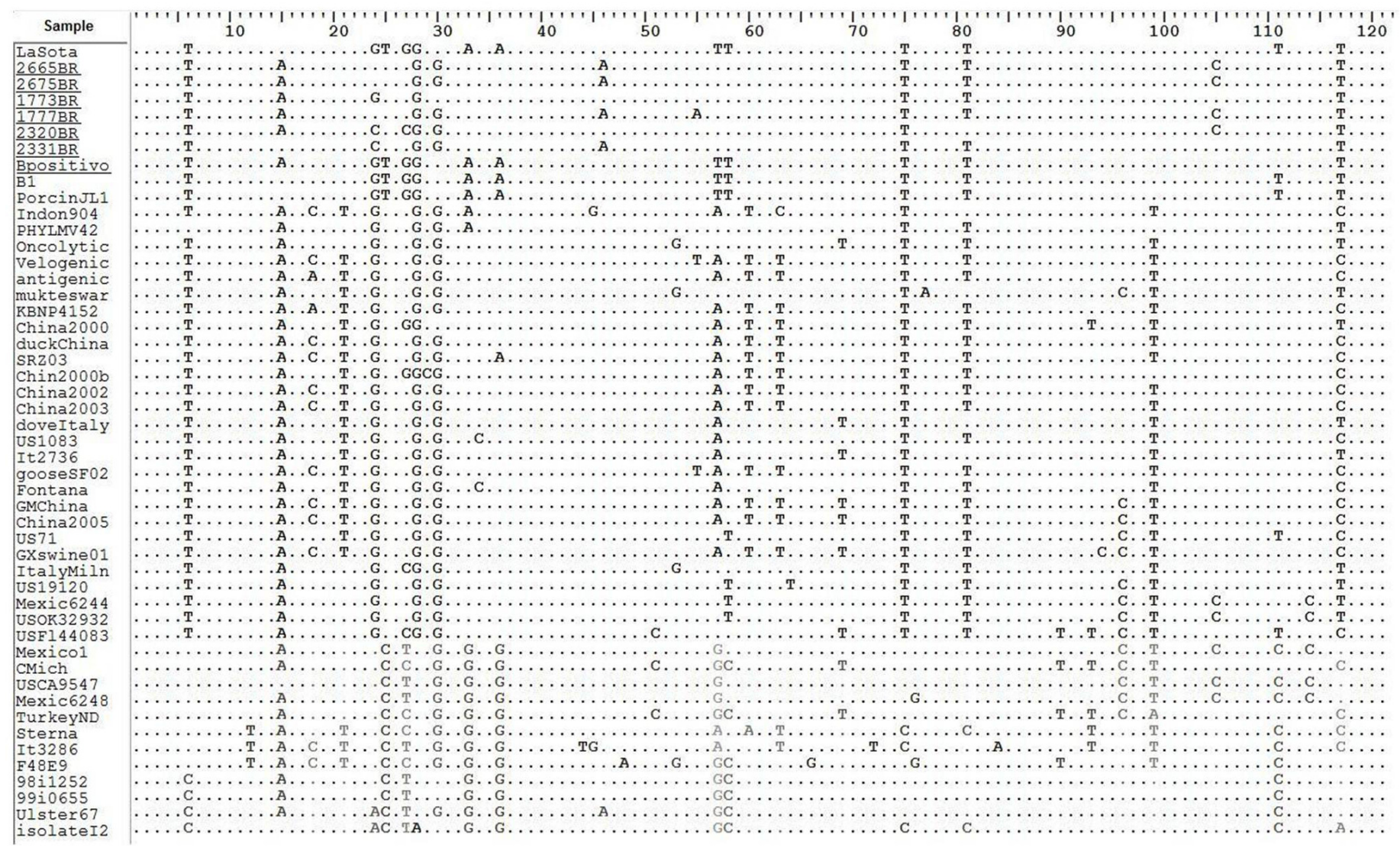

Figure 1 - Nucleotide alignment between the M gene region of Brazilian isolates and reference strains from GenBank. Consensus sequences were generated from each isolate, and the alignment shown is relative to the sequence of the prototype strain LaSota (GenBank accession number AY845400). The nucleotide sequence shown corresponds to the positions 4100 to 4220 in the strain LaSota. Identical residues are indicated by dots and nonsynonymous substitutions presented by nucleotide.

Although the genetic distance between the Brazilian isolates and the standard La Sota strain ranged from $7 \%$ to $11.7 \%$, they presented $100 \%$ identity of amino acid (aa) sequences, except for isolate 1777BR, which showed a single conservative a substitution of Leucine by Methionine (L019M), maintaining similar chemical properties.

\section{DISCUSSION}

In this study, we investigated the presence of NDV in wild and domestic asymptomatic birds from geographic areas considered the entry portal of NDV into Brazil. Reports on the occurrence of NDV in these remotes regions were not available. Because it has been suggested that nonvirulent ND viruses maintained in different wild bird species could cause NDV outbreaks in poultry, we considered it important to search for the presence of NDV in these reservoirs since the country is the largest exporter of chicken meat in the world.

Most of our samples were taken from waterfowl (70\% of the total, being $13.3 \%$ and $86.7 \%$ wild and domestic, respectively). These birds were prioritized because they deserve special consideration as ducks are reported to be readily infected with Newcastle disease virus and to be capable of spreading the virus. There are few reports of clinical NDV in ducks, but there are several accounts indicating a high rate of carriage of this virus by ducks. The problem is that these birds are usually clinically healthy, but may incubate and shed the virus.

The genus Calidris sp., often called "sandpipers", was another water fowl that stood out in this study: although accounting for only $2.7 \%$ of the total samples, they represented $28.6 \%$ of the positive samples ( 2 / 7 ). These were the only representatives of wild birds from which NDV was isolated. This result is a cause of concern because sandpipers are migratory birds and are found along almost all the Brazilian coast. A subspecies that occurs in Brazil, Calidris canutus rufa, can migrate up to a distance of $15,000 \mathrm{~km}$, connecting the Arctic to the southern most parts of the South American mainland, passing along the entire Brazilian coast (Buehler \& Piersma, 2008). 


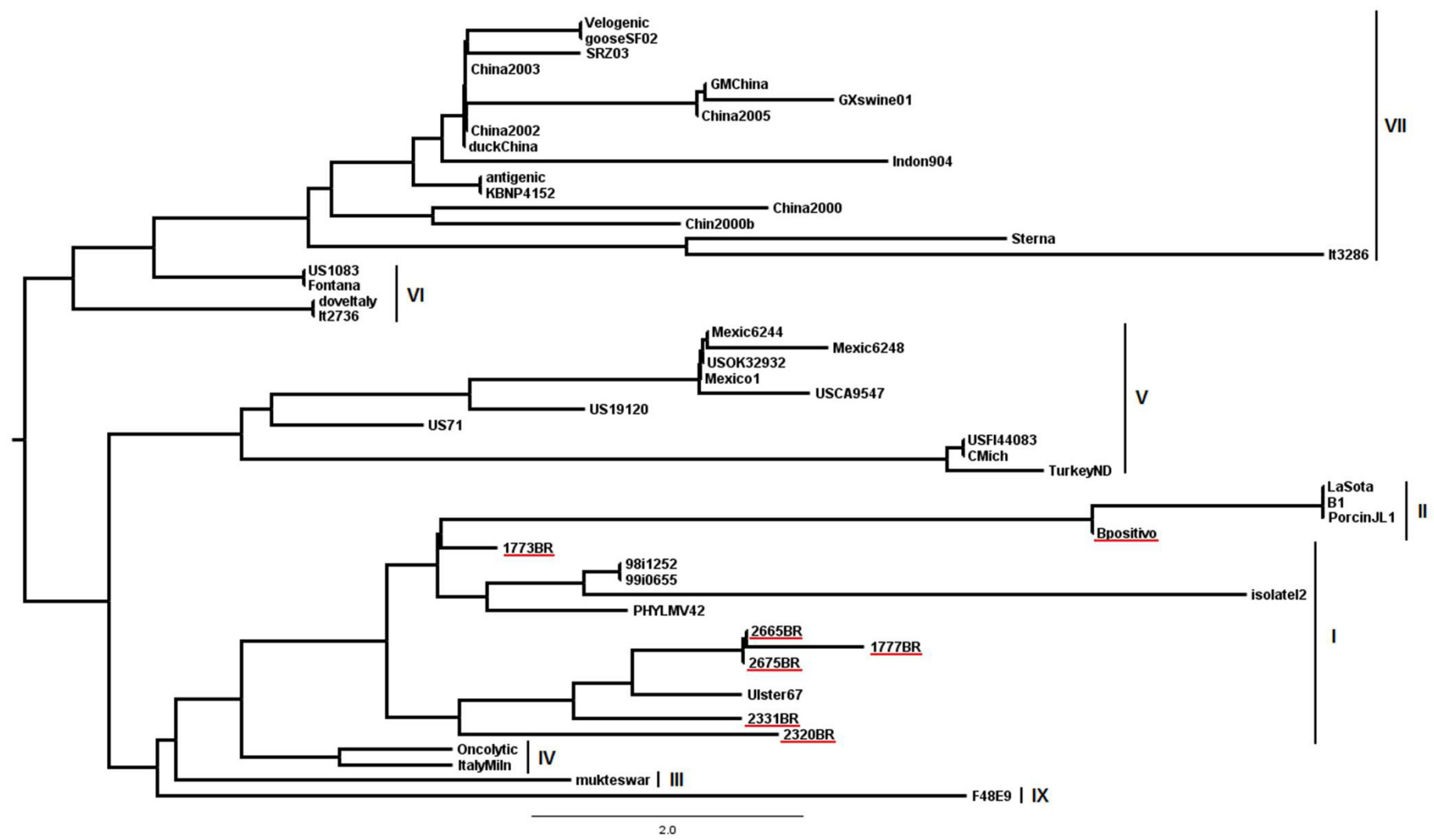

Figure 2 - Phylogenetic tree of the nucleotide sequences of the samples collected in different regions of Brazil, based on a 121 bp region of the $M$ protein gene.Bootstrap resampling of 100 replicates were obtained by PAUP* 4.0 (Distance method), comparing the Brazilian samples and the used positive control (both underlined) with partial cds sequences obtained in the GenBank (Accession numbers: AY845400, EU930425, FJ751801, FJ751802, FJ751797, FJ751798, FJ751800, FJ751799, AF309418, EU546165, AY444497, DQ097394, EU293914, AF431744, DQ839397, EF201805, DQ839397, DQ485248, DQ403244, EU167540, DQ485251, DQ485253, DQ485231, Y562989, AY562988, AY131275, AF473851, U25829, DQ486859, DQ485273, AY562990, EU346661, AF124442, AY444496, AY246047, AY444500, AY562986, AF124453, AF124451, AY438667, AY246048, U25836, AY865652, AY131279, AF089819, AY935493, AY935494, AY562991, AY935499).

Despite being isolated from embryonated chicken eggs in all positive samples, NDV was confirme donly by $\mathrm{qPCR}$ ( $\mathrm{Ct}$ between 35 and 39). In most cases the hemagglutination test did not produced positive results. Other authors have already described the difficulty of isolating NDV from clinical specimens from healthy adult birds, especially the low-virulence strains (Sakai et al., 2006). We believe that the viral concentration is so low that only the GPCR is able to detect it. Kubista et al. (2006) reported that the availability of the qPCR technology, highly efficient chemical detection, sensitive instruments, and optimized reactions allows the determination of the number of DNA molecules of a particular sequence in a sample with unprecedented accuracy and enough sensitivity to detect one single molecule. When a standard PCR reaction (not qPCR) was performed for the subsequent isolated nucleotide sequencing, the generated bands in agarose gel were so weak (data not shown) that was not possible to complete the sequencing of sample 844BR.

The high similarity between the isolates and the formation of a clade indicates that they are very close and share a common ancestor. Viruses with common temporal, geographical and antigenic parameters, or epidemiological studies data, are usually be classified in the same strain, and this has proven to be valuable when studying NDV spreading (Herczeg et al., 1999; Lomniczi et al., 1998; Yanget al., 1997).

In a previous study (Thomazelli et al., 2010), despite using phylogenetic analysis based on a small $\mathrm{M}$ gene fragment of $121 \mathrm{bp}$, we produced the same basic topology of a tree that used the total sequences of the main genes studied ( $\mathrm{F}$ or HN), which suggests that the use of relatively short sequences of different subgenetics regions is suitable for the identification of genotypes and does not significantly affect genetic distance values. 
Because in this study NDV was isolated from birds reared in poultry farms, as well as from wild and backyard water fowl from cloistered and remote locations with little or no interference from possible NDV infection caused by human actions, it is possible to infer that wild birds, migratory or not, and reared non-commercial birds, particularly waterfowl, act as low-pathogenicity NDV carriers or even reservoirs, and that probably the previous contact with the virus was natural, since serological results detected the presence of anti-NDV primarily in wild waterfowl (data not shown).

Non-virulent virus isolated from wild or domestic unvaccinated birds may represent an important NDV reservoir, particularly because the emergence of virulent NDV strains from non-pathogenic viruses maintained in wild birds has been often documented (Alexander et al., 1992; Collins et al., 1993 \& 1998; Gould et al., 2001). Therefore, the results presented here emphasize the importance of maintaining stringent biosecurity measures and the need to include small non-commercial bird rearing in surveillance programs.

Moreover, this study substantiates the maintenance of velogenic NDV-free status of Brazil, as determined by the World Organization for Animal Health (OIE). We do not rule out the possibility of the circulation of class I strains. Therefore, further studies are warranted, using more comprehensive methodologies, as described by Kim et al. (2008).

\section{REFERENCES}

Alexander DJ, Campbell G, Manvell RJ, Collins MS, Parsons G, McNulty MS. Characterization of an antigenically unusual virus responsible for two outbreaks of Newcastle disease in the Republic of Ireland in 1990. Veterinary Record 1992; 130:65-68.

Buehler DM, Piersma T. Travelling on a budget: predictions and ecological evidence for bottlenecks in the annual cycle of long-distance migrants. Philosophical Transctions of the Royal Society B. 2008; 363:247-266.

Camenisch G, Bandli R, Hoop R. Monitoring of wild birds for Newcastle disease virus in Switzerland using teal time RT-PCR. Journal of Wildlife Diseases 2008; 44(3):772-776.

Collins MS, Bashiruddin JB, Alexander DJ. Deduced amino acid sequences at the fusion protein cleavage site of Newcastle disease virus showing variation in antigenicity and pathogenity. Archives of Virology 1993; 128:363-370.

Collins MS, Franklin S, Strong I, Meulemans G, Alexander DJ. Antigenic and phylogenetic studies on a variant Newcastle disease virus using antifusion protein monoclonal antibodies and partial sequencing of the fusion protein gene. Avian Patholology 1998; 27:90-96.

Gould AR, Kattenbelt JA, Selleck P, Hansson E, Della-Porta A, Westbury $H A$. Virulent newcastle disease in Australia: molecular epidemiological analysis of viruses isolated prior to and during the outbreaks of 19982000. Virus Research 2001; 77:51-60.

Herczeg J, Wehmann E, Bragg RR, Travassos-Dias TM, Hadjiev G, Werner $\mathrm{O}$. et al. Two novel genetic groups (VIIb and VIII) responsible for recent Newcastle disease outbreaks in southern Africa, one (VIlb) of which reached southern European Archives Virolology1999; 144:2087-2099.

Kubista M, Andrade JM, Bengtsson M, Forootan A, Jonák J, Lind K. et al. Review: the real-time polymerase chain reaction. Molecular Aspects of Medicine 2006; 27:95-125.

Lomniczi B, Wehmann E, Herczeg J, Ballagi-Pordany A, Kaleta EF, Werner O. et al. Newcastle disease outbreaks in recent years in western Europe were caused by an old (VI) and a novel genotype (VII). Archives of Virology 1998; 143:49-64.

Office International des Epizooties.Newcastle disease, OIE Manual of Standards for Diagnostic Tests and Vaccines, chapter 2.1.15.2004

Sakai K, Yada K, Sakabe G, Tani O, Miyaji K, Nakamura M. et al. Serological and virological studies of newcastle disease and avian influenza in Slaughter-Age Ostriches (Struthio camelus) in Japan. Journal of Veterinary Medical Science 2006; 68(5):491-494

Thomazelli LM, Araujo J, Oliveira DB, Sanfilippo L, Ferreira CS, Brentano L, Pelizari VH, Nakayama C, Duarte R, Hurtado R, Branco JO, Walker $D$, Durigon EL. Newcastle disease virus in penguins from King George Island on the Antarctic region. Veterinarian Microbiology 2010;146: 155-160.

UBABEF - Brazilian Chicken Producers and Exporters Association.Annual report Ubabef 2010/11. Available at: http://www.abef.com.br/ubabef/ exibenoticiaubabef. php? notcodigo $=2761$.

Venturini KS, Sarcinelli MF, Silva LC. Características da carne de frango. Boletim técnico - [dissertação]. Universidade Federal of Espírito SantoUFES. Programa de Extensão Institucional.

Yang C, Chang YPC, Hwang JM, Sheih HK. Nucleotide sequence and phylogenetic analysis of Newcastle disease virus isolates from recent outbreaks in Taiwan. Avian Diseases 1997; 41:365-373. 